\title{
THE AGRICULTURAL COOPERATION ROLE WITHIN THE RELATION BETWEEN PRODUCER AND CONSUMER OF INFORMATION
}

\author{
Proffesor PhD Gabriel Popescu, Academy of Economic Studies of Bucharest \\ Proffesor PhD Victor Manole, Academy of Economic Studies of Bucharest
}

\begin{abstract}
The collapse of the communist regime in Romania, in December 1989, determined, at a very short time, the disappearance of the co-operative sector, once Law 18 (Land Law) was enforced in February 1991, which initiated the land ownership reform. In this context, the reactivation or more concretely, the reconfiguration of a new co-operative sector in full process of recognition and reconstitution of the private land ownership seemed impossible to achieve.
\end{abstract}

Keywords: co-operative sector, Common Agricultural Policy (CAP), European-type co-operative, knowledge transfer operation

JEL Codes: Q13

The collapse of the communist regime in Romania, in December 1989, determined, at a very short time, the disappearance of the co-operative sector, once Law 18 (Land Law) was enforced in February 1991, which initiated the land ownership reform.

In this context, the re-activation or more concretely, the reconfiguration of a new cooperative sector in full process of recognition and reconstitution of the private land ownership seemed impossible to achieve.

Yet, in August 1991, Law 36 was passed, which recognizes the opportunity or farmers' orientation towards the free market co-operative economy. This seemed to be a paradox, if we take into consideration the wounds inflicted to the Romanian peasants and rural areas through the agricultural production co-operatives of kolkhoz type.

According to the Common Agricultural Policy (CAP) orientations, the agricultural cooperative represents the main modality to solve up these two problems.

Such an appreciation is based first of all on the huge potential of these socio-economic structures. The potential of co-operatives results from their capacity to respond to the economic, social and institutional needs resulting from the rural development process, as well as from the possibilities to provide mechanisms for the organization and mobilization of material, financial and human resources.

At the same time, the European-type of co-operative, also operates as a business organization, where its capacity is manifested of direct acting as a socio-economic development agent. In the process of accumulation of assets, of widening the range of services provided, increase of supply, management performance increase, as well as increase of labour employment level, the co-operatives are actively involved in the modernization and efficiency increase of the activities in the rural area and/or agriculture.

In brief, the motivations of setting up and operating the cooperative structures in WestEuropean agriculture are based upon three particular aspects:

- Need to protect the farmers against the competition from the large companies manifested on the agricultural markets;

- Need to efficiently manage on their behalf the resources, mainly with reference to land resources; 
- Farmers' concern for getting actively involved and for their own benefit in the market relations, under their three-fold quality: producers, intermediaries and/or consumers.

All these motivations are a result of the classical principles on which the co-operatives are based, referring to voluntary participation, mutual aid, equal opportunities, and democracy. Furthermore, the group cohesion is maintained and guaranteed by the fact that no member is allowed to get advantages to the detriment of another member of co-operative, regardless of their nature.

But the European argument is not sufficient. It should be doubled by the efforts at national level that will be materialized into a new strategy promoting co-operation in agriculture; this strategy will in the first place lead to the elimination of the errors in the transition period, and secondly to redefining the role, involvement and coverage area of these units.

A minimum attention should be paid to the conjunctural premises that led to the recognition of the agricultural associations, as, in our vision, these represent the causes of the sinuous evolution of the association process in agriculture, following a decreasing trend, from 1991 to the present moment, as follows:

- Liquidation of agricultural production co-operatives, initiated by Law 18, in February 1991, led to the elimination of the privileges of the management staff in power from these units. No more privileges for the presidents of the agricultural production co-operatives, for the farm heads and chiefs of sectors, for their families and other people, who most often formed groups of interests, mafia-type of clans, imposed urgent solutions from the part of governance. This represented, in the first place, the determining cause that led to the fast adoption (at no more than six months) of the Law on Association, being the first from the legislative package announced by Law 18 in February the same year. The management positions of the new associations established by the former communist nomenclature from the liquidated co-operative farms were not occupied according to competitiveness criteria, but rather by force, intimidation, blackmail, political pressures, etc.

- Land restitution to former owners found an old peasantry, where the women population prevailed, which economically represented the most constraining factor to performance, a peasant household farm that lacked or almost lacked operating capital. The concern for the land into ownership, for farming this land, was and remained strongly rooted in peasants' mentality. That is why, from the peasants' point of view, the associations proved to be opportune, in the direction of operating land areas for which no sufficient means existed on the peasant farms. At a thorough analysis of these attitudes, it is not difficult to identify the causality factors, which are also found in the political decisions area.

- At present, from a temporal perspective, the association forms adopted on the basis of Law 36/1991, namely family associations, as non legal entities, and the agricultural associations as legal entities, seem to be atypical compared to the modern co-operative structures. The originality of these forms, that did not have any alternatives for almost 15 years, i.e. until the promulgation of the Law on Co-operatives in 2004, did not represent a factor of progress in Romanian agriculture. Furthermore, promoting the two alternatives (types) of association, motivated by the decision-makers as a democratic offer of peasants' willingness to associate, proved to be counterproductive as it gave rise to interpretations, confusions, corruption cases and other.

- The association offer, through the objectives provided by the law, seems to be all-inclusive and generous to the area of economic activities from agriculture and from the rural areas respectively. However, in reality, the "association on land" represented the first and the most important objective, which is different from the West-European experience, where the cooperation objectives are mostly found in the relations of associated farms with the market, with regard to input supply, production marketing and processing, etc. 
- The incentives provided to associated members represent another cause that constrains the association development process in agriculture. In fact, the association market depends on the value of incentives, which from the economic point of view connects the associated members, as land supply carriers and association, as demand representative. The law does not provide for a fixed amount or minimum or maximum limits of incentives, be they in cash, in kind or both in cash and in kind. As a result, the law left it to the two players, i.e. associated member and association, to negotiate the size and form of incentives, as well as the other association conditions. Apparently, the free market democracy principles are respected. Yet, in practice, the process has not adequately operated. The causes are the following:

- Throughout the transition period, the land supply on the land market was higher than the demand. Hence, all the economic categories specific to the land market, i.e. the land price, rent or dividends were under sized compared to their real value;

- The land demand representatives, i.e. buyers, lessees, associations, co-operatives have constantly had a privileged, monopoly position in the negotiation of conditions, of incentives on the land market inclusively.

- All the agrarian policy approaches after December 1989 recognize the association opportunity, highlighting its advantages for a performant agriculture. Yet, the association opportunity idea, be it from public or scientific perspective, refers to the point of view of the association as an entity rather than of the associated members. It is obvious that the incentives versus the decent living needs of the associated members are not attractive. Their lack of attractiveness is due both to their value related to the unit of area, as well as to the very low land property size of the peasant holdings.

Under a hypothetical rationale, yet based on true statistical information, the conclusions were the following:

- $\quad$ The average area per peasant holding $=2.5$ ha, out of which:

Area under garden, buildings and other utilities $=0.5$ ha

Area to contribute to association $=2.0$ ha

- Dividends: $600 \mathrm{~kg}$ wheat $/ \mathrm{ha} * 0.6 \mathrm{RON} / \mathrm{kg}=720 \mathrm{RON}$

- $\quad$ Total expenses per farmer holding $=945.51 \mathrm{RON} / \mathrm{month}^{1}$ holding

It results that the incomes that can be obtained by an average holding from land lease, not considering the land under buildings, garden or other utilities total about $720 \mathrm{RON} /$ year, which cannot cover the necessary expenses per holding, which according to the official statistical data reach over $945 \mathrm{RON} / \mathrm{month}$, i.e. about $11,340 \mathrm{RON} /$ year.

Taking into consideration the previous findings, one cannot be surprised by the low share of the associative sector and by its decreasing trend (Table 1).

Table no. 1

Dynamics of agricultural associations

\begin{tabular}{|l|c|c|c|c|c|}
\hline \multicolumn{1}{|c|}{ Specification } & $\mathrm{U} / \mathrm{M}$ & 1994 & 1996 & 1998 & 2001 \\
\hline Total number of & & 17,711 & 18,866 & 10,753 & 10,870 \\
associations, out of which: & & 3,970 & 3,759 & 3,578 & 4,376 \\
- Legal entities & & 13,741 & 15,107 & 7,175 & 6,494 \\
- Family associations & & & & & \\
\hline
\end{tabular}

'Romania's Statistical Yearbook, 2006, p 234 


\begin{tabular}{|c|c|c|c|c|c|}
\hline $\begin{array}{l}\text { Total area, out of which: } \\
\text { - Legal entities } \\
\text { - Family associations }\end{array}$ & $\begin{array}{l}\text { thou. ha } \\
\text { thou. ha } \\
\text { thou. ha }\end{array}$ & $\begin{array}{l}3,307 \\
1,770 \\
1,537\end{array}$ & $\begin{array}{l}3,191 \\
1,751 \\
1,440\end{array}$ & $\begin{array}{c}2,492 \\
1,542 \\
950\end{array}$ & $\begin{array}{c}2,475 \\
1,685 \\
790\end{array}$ \\
\hline $\begin{array}{l}\% \text { of total area under } \\
\text { associations in total } \\
\text { agricultural area of the } \\
\text { private sector }\end{array}$ & $\%$ & 29.5 & 27.7 & 21.4 & 19.4 \\
\hline $\begin{array}{l}\text { Average area per } \\
\text { association, out of which: } \\
\text { - Legal entities } \\
\text { - Family associations }\end{array}$ & $\begin{array}{l}\text { ha } \\
\text { ha } \\
\text { ha }\end{array}$ & $\begin{array}{l}186.7 \\
446.0 \\
112.0\end{array}$ & $\begin{array}{c}169.1 \\
466.0 \\
95.0\end{array}$ & $\begin{array}{l}231.7 \\
435.0 \\
132.0\end{array}$ & $\begin{array}{l}227.7 \\
385.0 \\
121.0\end{array}$ \\
\hline
\end{tabular}

Source: Ministry of Agriculture, Food and Forests

- The involution of the associative sector in agriculture in the transition period featured different rates. For example, in the period 1994-2001, the total number of associations declined by about 7,000 units, i.e. by $38.6 \%$; in the period $2001-2005$, the association disappearance rate increased; thus, in the year 2005 not more than 1,630 were operating (9.2\%), compared to 17,711, in 1994 (tables 1 and 2).

Table no. 2

Structure of agricultural holdings by their legal status, 2005

\begin{tabular}{|c|c|c|c|c|}
\hline $\begin{array}{l}\text { Legal status of } \\
\text { agricultural holdings }\end{array}$ & $\begin{array}{l}\text { Total } \\
\text { agricultural } \\
\text { holdings } \\
\text { (number) }\end{array}$ & $\begin{array}{l}\text { Agricultural } \\
\text { holdings that } \\
\text { use agricultural } \\
\text { land and raise } \\
\text { animals } \\
\text { (number) }\end{array}$ & $\begin{array}{c}\text { Agricultural } \\
\text { holdings only } \\
\text { with utilized } \\
\text { agricultural } \\
\text { area } \\
\text { (number) }\end{array}$ & $\begin{array}{l}\text { Agricultural } \\
\text { holdings } \\
\text { only with } \\
\text { animals } \\
\text { (number) }\end{array}$ \\
\hline $\begin{array}{l}\text { Individual agricultural } \\
\text { holdings }\end{array}$ & 4237889 & 3315797 & 787607 & 134485 \\
\hline Legal entity units: & 18263 & 2532 & 15311 & 420 \\
\hline $\begin{array}{l}\text { Agricultural } \\
\text { companies/associations }\end{array}$ & 1630 & 212 & 1402 & 16 \\
\hline $\begin{array}{l}\text { Commercial } \\
\text { companies with } \\
\text { majority private capital }\end{array}$ & 4574 & 917 & 3408 & 249 \\
\hline $\begin{array}{l}\text { Commercial } \\
\text { companies with } \\
\text { majority state capital }\end{array}$ & 250 & 38 & 200 & 12 \\
\hline $\begin{array}{l}\text { Public administration } \\
\text { units }\end{array}$ & 4818 & 589 & 4161 & 68 \\
\hline Co-operative units & 108 & 12 & 77 & 19 \\
\hline Other types & 6883 & 764 & 6063 & 56 \\
\hline Total & 4256152 & 3318329 & 802918 & 134905 \\
\hline
\end{tabular}

Source: Structural Farm Survey - 2005, tome I General data, NIS, 2006

Also at the end of 2005, one year after the enforcement of the Law on Co-operation in agriculture, the number of agricultural co-operatives totalled only 108 units, a non-significant figure if we refer to the sector potential, and mainly to the opportunities these units can provide, mainly to the peasant holdings. 
The errors of the past, with special reference to the activity of agricultural associations after 1991, are also repeated with regard to the agricultural associations, as 77 co-operative units, i.e. $71.3 \%$ of total, have as activity object only land operation, 17 have a mixed activity (crop and livestock production), and 12 operate in the livestock sector. The statistical data do not refer to any agricultural co-operative unit with activity object in the area of input supply, processing or sale of agricultural production; it is in these fields that, in the CAP vision, these units should operate with priority.

Considering the above-mentioned phenomena, we consider it opportune to reformulate, in modern terms, the national policies, which should have as objective the agricultural producers' orientation to co-operative structures with activity in the marketing, management, consultancy, knowledge transfer areas, and less in land operation.

In the future society and not in a very remote period of time, among the above-mentioned objectives, the transfer of knowledge will be, in our opinion, the key of the agricultural co-operative activity. That is why we shall next try and design the frame elements by which we define the role of agricultural co-operatives in the knowledge transfer equation.

The knowledge transfer operation implies first of all the conceptualization of the frame elements, namely: definition of objectives, establishment of working modalities, procedures and techniques, identification of institutional and market players involved in the information flow, from producers to consumers.

The objectives of the transfer of knowledge, under a synthetic but explicit approach, may be the following:

- Implementation of performant technologies - the liberalization of commercial flows obliges the rural entrepreneurs to use the best available technologies (BAT) in order to have commercial advantage;

- $\quad$ Obtaining new products;

- $\quad$ Nature conservation and environmental factors protection;

- $\quad$ Obtaining non-food agricultural products and organic food products;

- Initiation, support and development of non-agricultural economic activities - tourism (eco-tourism, agro-tourism, cultural tourism, etc.), trade, agro-processing, manufacturing handicraft products, etc.;

- $\quad$ Increasing the incomes and living standard for all rural people.

Furthermore, regardless of the activity type, the access to knowledge becomes a determining factor, as the rural supply of products and services should be consumer-oriented, to get adapted to the changes produced in consumers' preferences, as well as to the increased exigency in the analysis of the quality of products and services.

On the basis of these benchmarks, we consider that the rural players have double motivation in intensifying their efforts to have access to knowledge and to get ready in order to best use the economic and natural potential of information through consumption.

The modalities to transmit the new information are many, but generally they are centered upon the new information and communication technologies as these permit the increase of the political, social and economic participation; the easy access to and dissemination of knowledge and information; initiation of business, increase of visibility and isolation diminution. Other means are face-to-face communication, leaflets, newsletters, brochures, events, etc.

The knowledge transfer services in the rural area are represented by: extension, qualification, research, information and communication technologies.

An important benchmark in the establishment and operation of co-operatives involved in the knowledge transfer area is represented by the social principles of agricultural extension. For the extension activity at agricultural co-operatives level to be efficient, the following key-problems should be targeted: 
- Including and involvement of the co-operative in a research network, with regional, national or international coverage areas, where academic research structures and rural development centers are found;

- Respect of the social principles of agricultural extension.

In the category of modalities, procedures and techniques that the agricultural co-operatives can use in the knowledge transfer activity, the following are also worth mentioning:

- Organization of thematic events, meetings, visits;

- $\quad$ Facilitating the financial support to investments through grant applications;

- Establishing the business/producers' groups and their connection to the specialized research network;

- $\quad$ Brand posting services;

- Grant-based financial support - from the funds that it receives, the knowledge center can allocate a certain segment in order to support training, qualification, information activities, study tours based upon the requests;

- $\quad$ Free of charge or subsidized consultancy;

- Visits to farmers/entrepreneurs represent the activity with the greatest contribution in terms of knowledge transfer. In this respect, it is important to prepare and involve the extension officer who gets into direct contact with the entrepreneurs or farmers and who by combining the professional abilities with the affective attitude and involvement has a key-role in influencing the decision made by the rural players;

- Organization of flexible training courses;

- Data base management with the entrepreneurs and farmers;

- Establishment and maintenance of relations with the academics and the governmental and professional organizations;

- Assistance in business plan start - up and development;

- Management of business incubator units;

- Ecologic consultancy;

- $\quad$ Management of business networks;

- $\quad$ Promoting the debates;

- Evaluation of network animation practices;

- Utilization and sharing the good practice and experience;

- Designing methodologies for the local and national players.

Taking into consideration the above-mentioned theoretical benchmarks, we propose the following knowledge transfer scheme in rural areas, by stages and involved socio-economic structures.

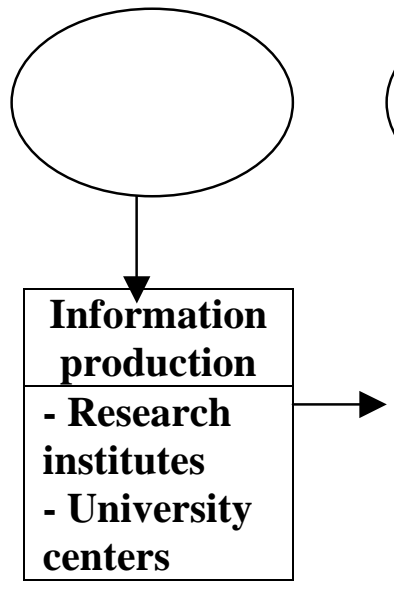

Fig. no.1 -
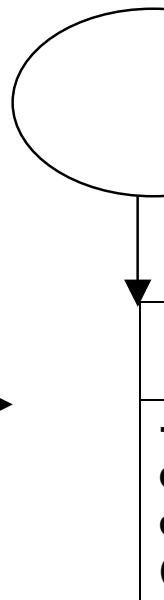
private)
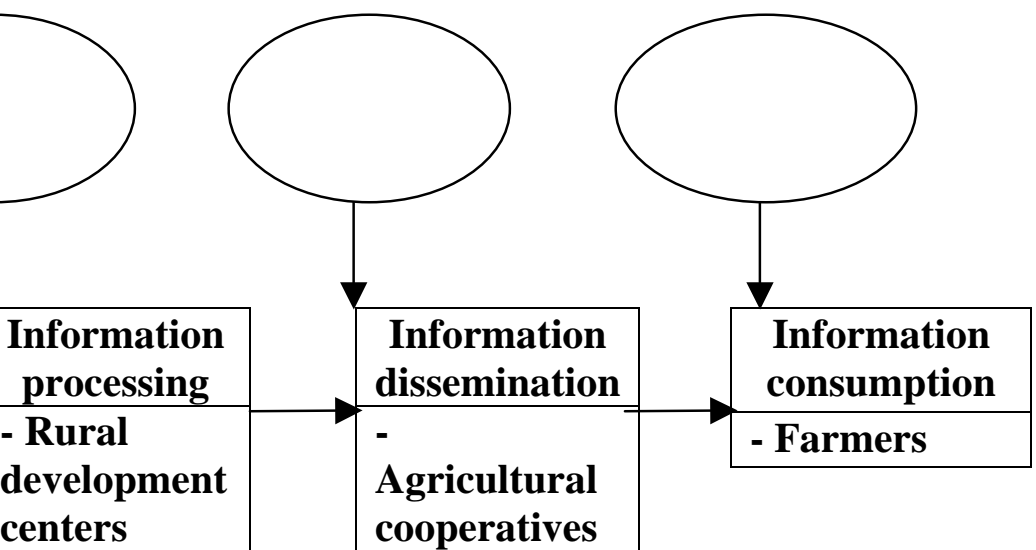

Knowledge transfer scheme, by stages, objectives and involved socio-economic players 
Compared to the present situation, where the knowledge transfer is operated between the players from stages I, II, and IV, the scheme proposed by us brings stage III as a novelty, focusing upon the agricultural co-operative, which has as objective information dissemination to farmers.

The agricultural co-operative has a double role in the information transfer process:

1. ensuring farmers' access to information;

2. preparing the farmers, in their quality of consumers, to use the economic and natural potential of information.

Furthermore, the co-operative also has to respond to the needs and rigors of information ordering. By ordering the information, the information is not amplified, but the economic advantages of its logical algorithm are used at maximum (Georgescu- Roegen, 1996).

In fact, and this is a determining factor, from the point of view of the role and importance of the co-operative in the information transfer equation, the greatest effort in the transfer chain is generated by the information consumers, and not by the information suppliers. The farmer is obviously the main consumer and beneficiary of the information transfer in the rural area.

"In the case of information, the production process preserves in it a relatively low economic and natural potential. It is consumption that contributes to the information value amplification, exploiting its synergetic resource feature. But at the same time, we should take into consideration that the preparation of this amplifying consumption is very costly. (...) While the information production is relatively cheap (What was the cost paid by the society for Newton's "maintenance"? Relatively low cost!), the preparation of the consumption process makes the assimilation of the respective information be as expensive as the extraction of diamonds from the African mines. Reading and understanding a formula from Physics were preceded by a huge social effort for schooling, typing the manuals, extension, etc."2.

It would be nonsense to think that, in a world where the changes are extremely fast, it is only the farmers who will take over and use the new information. The arguments, given the environment where these are operating, are useless. Here lies the co-operative role in the knowledge transfer equation.

The knowledge transfer benefits, in the European Commission's vision, are at three levels ${ }^{3}$ :

- $\quad$ for the academic environment - there are financial benefits, but besides these there are a series of less tangible benefits, from a better correlation between the research effort and the needs of the society and of the economy;

- for the economy economy - the research institutes can better direct their efforts on the specific needs of the economy as the knowledge transfer will increase the capacity of enterprises to use the knowledge and information developed by public research, trust will increase, research organization will be improved and a better matching of interests and benefits will be obtained;

- $\quad$ for the society - the benefits result from the fact that the public authorities have the possibility to make sure that their investments in research have an optimum socioeconomic impact, materialized into new products, new jobs and enterprises. Furthermore, the knowledge transfer at national or regional level has a strong impact upon local development.

\footnotetext{
2 Bran, P., Valoarea informației, în volumul Evaluarea şi gestionarea riscurilor ecologice, Editura ASE, Bucureşti, 2006, p.14-20

3 Knowledge transfer between research institutions and industry, MEMO/07/127, www.europa.eu, 2007
} 
There are many approaches to facilitate the knowledge transfer among the rural producers. These can be grouped into two categories depending on the starting point of information that lie at the basis of building up the operational structures: approaches starting from a central level, based upon information that describe the overall picture of the rural economy (top-down approach) and approaches starting from the local rural realities (bottom-up approach).

At world level, many initiatives have been developed targeting the access to information and the preparation of information consumption in the rural area. These were based upon different approaches, covered areas of different sizes and had access to various financial support programs. Many such initiatives were replicated so as to stimulate the rural areas from Africa, South-America and South-East Asia. Although the names are quite different - center, gateway, initiative, network, etc. - the knowledge transfer intermediary can be assimilated to an information center or node.

The agricultural co-operative should be established as a gateway to a series of incentives for the development of the entrepreneurial action - information, consultancy, and access to funds, training. In addition, the co-operative should help the rural entrepreneurs to be more innovative through the illustration of the new opportunities and through their mobilization and assistance to best use these opportunities. The agricultural co-operative must facilitate the teamwork and collaboration, and foster partnership development.

From the conceptual point of view, the co-operative forms an $<<$ informational nucleus $>>$ where the inputs are the information supplied by the farmers and the rural entrepreneurs, the scientific research results, the relevant legislative and political information, the financial support opportunities, etc., and the outputs are the responses to the local players' needs. In the $<<$ informational nucleus $>>$ the information needs are matched with the information supply, through applied research work inclusively, and the responses are formulated. The information flow is closed, thus creating the premises for continuous improvement.

In order to play the role of knowledge intermediary, it is recommended that the involved cooperative units should provide services on a free of charge basis or strongly subsidized services. Thus, the competition with the consultancy firms will be avoided and a wide access will be ensured. As regards the support capacity, the necessary funds can be obtained on project basis from the regional development agencies, from European funds, etc.

\section{References}

1. Bran, P., Valoarea informației, în volumul Evaluarea şi gestionarea riscurilor ecologice, Editura ASE, Bucureşti, 2006, p.14-20

2. *** Romania's Statistical Yearbook, 2000, 2005

3. $* * *$ European Commission, Directorate General for Agriculture and Rural Development, Agriculture in the European Union, Statistical and Economical Information, 2005, February 2006

4. *** Ministry of Agriculture, Food and Forests

5. *** Structural Farm Survey - 2005, tome I General data, NIS 2006

6. General Agricultural Census

7. *** www.europa.eu, Knowledge transfer between research institutions and industry, MEMO/07/127, 2007

8. Law 36/1991

9. Law $18 / 1991$

10. Law $56 / 2004$

11. Law $1 / 2005$ 